\title{
HYDROGEN-ION CONCENTRATION AND ANTISEPTIC POTENCY, WITH SPECIAL REFERENCE TO THE ACTION OF ACRIDINE COMPOUNDS. ${ }^{1}$
}

\author{
By C. H. Browning, R. Gulbranshan, and E. L. Kennaway. \\ From the Bland-Sulton Thstitute of Pulhology, Middlescx Mroswial, Lomdon.
}

\section{(A Report to the Medical Research Committee.)}

Expenmex's which we carried out on the antiseptic potency of acridine compounds in urine (hitherto umpublished) showed that a much greater effect was produced when the reaction was alkaline than when it was acid. This held both in the case of staphylococcus and B. coli, but was more marked with the latter.

Example.-Date of Experiment, July 24, 1917.-Bactericidal action of diamino-acridine methyl-chloride in urine (1 c.c. inoculated with $0 \cdot 1$ c.c. of I : 20,000 dilution of a 24 -hour peptone-water culture of 7. coli $i$.

\begin{tabular}{|l|c|c|}
\hline \multirow{2}{*}{ Reaction to Litmus Paper. } & \multicolumn{2}{|c|}{ Concentration of Antiseptic. } \\
\cline { 3 - 4 } & $\begin{array}{c}\text { Permitting vigorous } \\
\text { growth. }\end{array}$ & $\begin{array}{c}\text { Producing sterility in } \\
\text { twenty-four to forty-eight } \\
\text { hours. }\end{array}$ \\
\hline Acid. . & $1: 2000$ & (Not atscertained) \\
Amphoteric & 1.4000 & $1: 2000$ \\
Alkaline . . & (Not ascertuined) & $1: 20,000$ \\
\hline
\end{tabular}

The controls without antiseptic yielded vigorous growth in all cases. The reaction was adjuster by adding phosplinate solutions.

Work on this line was not continued at the time, since practical applications were the chief object, and clinical trials indicated that the most promising compound then available (diamino-acridine sulphate), could not be administered in doses sufficiently high to cure cases of chronic B. coli pyelitis. Independently Davis and White $\left(1918^{1}\right) \mathrm{ob}-$ tained results which corresponded with our observations on the influence of reaction, and Graham-Smith's work $\left(1919^{2}\right)$ is also in agreement.

Further investigation has shown that comparatively small variations. in hydrogen-ion concentration $(H)$ exercise a great inlluence on the

\footnotetext{
${ }^{1}$ Received July 26, 1919.
} 
antiseptic potency of acridine compounds. Thus the results shown in Table I. were obtained by altering the hydrogen-ion concentration of the medium $(0.7$ per cent. peptone water containing 0.35 per cent. $\mathrm{NaCl})$, as determined by the usual indicators.

Table I.

Inoculation of 1 c.c. Medium with 0.1 c.c. of $1: 1000$ Dilution of a 24-Hour Peptone-Water Culjure of $B$. coli.

\begin{tabular}{|c|c|c|c|c|c|c|}
\hline \multirow{2}{*}{\multicolumn{2}{|c|}{$\begin{array}{c}\text { II of Peptone } \\
\text { Water Medium. }\end{array}$}} & \multirow[b]{2}{*}{$\begin{array}{l}\text { Solution of } \\
\text { approximately } \\
\text { corresponding } \\
\text { Reaction. }\end{array}$} & \multicolumn{2}{|c|}{$\begin{array}{l}\text { Concentration of Diamino- } \\
\text { Acridine Methyl-Chloride. }\end{array}$} & \multicolumn{2}{|c|}{$\begin{array}{c}\text { Concentration of Mercuric } \\
\text { Chloride. }\end{array}$} \\
\hline & & & $\begin{array}{l}\text { Pernitting } \\
\text { vigorous } \\
\text { growth. }\end{array}$ & $\begin{array}{c}\text { Producing } \\
\text { sterility in } \\
\text { twenty-four } \\
\text { to } \\
\text { forty-eight } \\
\text { hours. }\end{array}$ & $\begin{array}{l}\text { Permitting } \\
\text { vigorous } \\
\text { growth. }\end{array}$ & $\begin{array}{c}\text { Producing } \\
\text { sterility in } \\
\text { twenty-four } \\
\text { to } \\
\text { forty-eight } \\
\text { hours. }\end{array}$ \\
\hline $\begin{array}{l}10^{-4} \\
10^{-5}\end{array}$ & . & $\left.\begin{array}{l}\text { N/10,000 acid } \\
N / 100,000,,\end{array}\right\}$ & $1: 4,000$ & $1: 2000$ & $1: 4,000,000$ & $1: 2,000,000$ \\
\hline $\begin{array}{l}10^{-5} \\
10^{-7}\end{array}$ & . $\quad$. & $\left.\begin{array}{l}\text { N/1,000,000 acid } \\
\text { "Neutral" }\end{array}\right\}$ & $1: 40,000$ & $1: 10,000$ & $1: 2,000,000$ & $1: 1,000,000$ \\
\hline $\begin{array}{l}10^{-8} \\
10^{-9}\end{array}$ & $\begin{array}{ll}\cdot & \cdot \\
\cdot & \cdot\end{array}$ & $\begin{array}{l}\mathrm{N} / 1,000,000 \text { alkali } \\
\mathrm{N} / 100,000,, j\end{array}$ & $1: 100,000$ & $1: 40,000$ & $1: 1,000,000$ & $1: 400,000$ \\
\hline $10^{-11}$ & . & $\mathrm{N} / 1,000$ & $1: 400,000$ & $1: 200,000$ & $1: 1,000,000$ & $1: 400,000$ \\
\hline $\begin{array}{r}\text { Serum } \\
\text { at } 5 \\
(\mathrm{H}=\end{array}$ & $\begin{array}{l}\text { heated } \\
5^{\circ} \mathrm{C} . \\
\left(0^{-8}\right)\end{array}$ & $\cdots$ & $1: 1,000,000$ & $1: 200,000$ & $1: 20,000$ & $1: 10,000$ \\
\hline
\end{tabular}

Peptone-water medium of the above hydrogen-ion concentrations, without antiseptic, and also serum, yielded vigorous growths in all cases.

The results were similar when the hydrogen-ion concentration was adjusted by means of (1) $\mathrm{HCl}$ or $\mathrm{NaOH}$, or (2) phosphate solutions; but alkaline phosphate seemed somewhat more effective than $\mathrm{NaOH}$ in enhancing the antiseptic action.

In order to test further the influence of hydrogen-ion concentration, alkaline phosphate was added to heated ox serum $\left(55^{\circ} \mathrm{C}\right.$. for half to one hour). It was found that the antiseptic potency in the serum was further increased thereby, when an amount of phosphate was added which by itself had no effect on the growth of $B$. coli in the serum.

The enhancing effect of reduced hydrogen-ion concentration was. obtained with other acridine compounds, e.g., diamino-acridine hydrochloride and the methyl-chloride of acridine yellow.

It is to be noted that the results do not depend merely on alterations in the nutrient properties of the medium, since similar experiments with mercuric chloride showed that increase in the hydrogen-ion concentration caused augmentation of bactericidal action, instead of decrease, as with the acridine derivatives. But the dose of mercuric chloride which was required to produce sterility in serum 
was forty times greater than that which sufficed in peptone water of the same hydrogen-ion concentration.

Accordingly, the effectiveness of the acridine antiseptics in serum is to be ascribed mainly to two factors:

1. The hydrogen-ion concentration of the serum, and

2. Lack of combination of a chemical or physical character between the acridine compounds and constituents of the serum.

This explanation is in accord with our previous observation that these antiseptics acted as powerfully in cerebro-spinal fluid containing a trace of protein as in serum.

As regards the practical testing of antiseptics, in addition to the importance of taking into account the time rate of lethal action when estimating potency, previously drawn attention to, the present investigation emphasises the significance of hydrogen-ion concentration, since the potency of the same substance may vary in the ratio of $1: 100$, according to the hydrogen-ion concentration of the medium in which it is tested.

\section{REFERENCES.}

1. Davis and White . . . Journ. Urol., 1918, vol. ii. p 299.

2. Graham-Smith . . . . Journ. Hyg., Cambridge, 1919, vol. xviii. p. 1. 